\title{
Correction of physiological, biochemical and productive indicators of farm animals using mineral sorbent
}

\author{
Galina Vasilyevna Molyanova*, Vasiliy Semyonovich Grigoryev, and Vladimir Viktorovich Ermakov \\ Samara State Agricultural University, 446442 Kinel, Samara region, Russia
}

\begin{abstract}
When feeding 30-180-day old calves with mineral sorbent vodnite, the number of red blood cells increases by $4.17 \%(\mathrm{p} \leq 0.05)$, the hemoglobin level increases by $9.4 \%(\mathrm{p} \leq 0.05)$, total protein content by $6.44 \%(\mathrm{p} \leq 0.01)$, albumin content - by $4.60 \%(\mathrm{p} \leq 0.001)$, the phagocytic activity of leukocytes - by $12.42 \%(p \leq 0.05)$, the bactericidal activity - by $6.47 \%(\mathrm{p} \leq 0.05)$, the lysozyme activity - by $10 \%(\mathrm{p} \leq 0.05)$, the average daily weight gain of calves - by $7.4 \%$, the live weight - by $7.6 \%(p \leq 0.01)$. In fresh cows fed with vodnite, physical and biochemical characteristic improve and the gross milk yield increases by $45-84$ $\mathrm{kg}(\mathrm{p}<0.05)$. Vodnite used for cattle increases the genetic productivity.
\end{abstract}

\section{Introduction}

In the conditions of increasing technogenic and anthropogenic pressure on the environment, the problem of environmentally friendly additives, immunocorrectors and natural minerals in livestock breeding is relevant. Zeolites can be used as well since they have a unique combination of ion exchange, catalytic, adsorption, detoxification, deodorizing, prolonging effects on the animal body [1-4].

Macro- and micronutrients of natural minerals form macro- and microtubules; natural minerals have adsorption properties [5].

The cost of zeolites is low. Their use increases the absorption of nutrients, makes it possible to reduce feed consumption [6-9].

It is advisable to use zeolites, bentonites, flasks, dolomites, tripoli and other aluminosilicate rocks to eliminate the mineral deficiency in local feed resources, which can prevent secondary immunodeficiency states, macro- and microelementoses, and stimulate natural resistance and productivity of farm animals [10].

One example of local zeolites is natural vodnite. Natural mineral vodnite extracted at the Vodinsk deposit of Krasnoyarsk district of Samara region is a natural sedimentary sulfur scented mineral. It is located in an ecologically safe area, where no foci of dangerous, quarantine diseases of humans, animals and birds have been established.

The color varies from light to gray-yellow. It crumbles well, boils in contact with a $10 \%$ hydrochloric acid. The results of the quantitative and qualitative content of chemical elements are shown in Table 1.

Sulfur $(47.37 \%)$, carbon and iron $(9.87$ and $9.37 \%$, respectively) are the predominant elements in vodnite. The concentration of heavy metals is safe for animals (mg / kg): copper - 0.440; zinc - 0.330; cadmium - 0.070; lead is 0.008 .

No mercury and arsenic were found. This natural mineral supplement is harmless to warm-blooded animals and does not have allergenic, teratogenic, toxic and mutagenic effects.

The pharmacological mechanism of vodnite involves the enterosorption method based on the binding and elimination of toxic substances from the body: microflora products, bacterial toxins, tissue breakdown products.

The porous structure allows for the sorption of endoand exotoxins with various molecular weights and makes it possible to increase the digestibility of feed nutrients, normalize the morphophysiological and immune status, and increase the productivity of animals.

Table 1. The concentration of chemical elements in vodnite

\begin{tabular}{|c|c|c|c|c|c|c|c|c|c|c|c|c|c|c|c|}
\hline $\begin{array}{c}\text { Place of } \\
\text { sampling }\end{array}$ & $\mathrm{C}$ & $\mathrm{O}$ & $\mathrm{Na}$ & $\mathrm{Mg}$ & $\mathrm{AI}$ & $\mathrm{Si}$ & $\mathrm{P}$ & $\mathrm{S}$ & $\mathrm{CI}$ & $\mathrm{K}$ & $\mathrm{Ca}$ & $\mathrm{Cr}$ & $\mathrm{Fe}$ & $\mathrm{Ni}$ & $\begin{array}{c}\text { Total } \\
(\%)\end{array}$ \\
\hline 1 & 19.4 & 6.3 & 0.3 & 0.5 & 0.3 & 2.2 & 1.5 & 27.9 & 1.9 & 2 & 27.5 & 0.3 & 9 & 0.9 & 100 \\
\hline 7 & 5.6 & 4.1 & 0.3 & 0.7 & 0.3 & 0.8 & 2.1 & 57.5 & 1.3 & 1 & 22.6 & 0.1 & 3.5 & 0.1 & 100 \\
\hline 8 & 4.6 & 3.7 & 0.1 & 0.6 & 0.2 & 0.5 & 1.5 & 56.7 & 1.4 & 0.6 & 14.1 & 0.3 & 15.6 & 0.2 & 100 \\
\hline Average & 9.87 & 4.7 & 0.23 & 0.6 & 0.7 & 1.17 & 1.7 & 47.37 & 1.53 & 1.2 & 21.4 & 0.23 & 9.37 & 0.4 & 100 \\
\hline
\end{tabular}

* Corresponding author: Molyanova@yandex.ru 


\section{Methods and materials}

Scientific research was carried out in the conditions of ZAO "Lunacharsk" of Stavropol district of Samara region and the research laboratory of the faculty of biotechnology and veterinary medicine of Samara State Agrarian University. 60 fresh cows were used in compliance with the principle of analogues.

Animals of the control group were fed with basic products. During the first lactation, cows of the experimental group were fed with vodnite at the rate of $3.0 \%$ of the dry matter of the feed. We studied the dynamics of the clinical and physiological state, the hematological, biochemical and immunological status of cows, quantity and quality of milk on the $10-305^{\text {th }}$ day of lactation.

\section{Results}

In control animals, the live weight decreased since the $10^{\text {th }}(491.3 \pm 3.8 \mathrm{~kg})$ to the $240^{\text {th }}$ day of lactation $(486.2$ $\pm 3.9 \mathrm{~kg})$. It was followed by a slow increase to the $30^{\text {th }}$ 5 day $(492.0 \pm 3.1 \mathrm{~kg})$. In cows of the experimental group, the live weight gradually decreased since the $10^{\text {th }}$ to the $60^{\text {th }}$ day of lactation $(490.5 \pm 4.1 \mathrm{~kg}$ versus 489.0 $\pm 4.3 \mathrm{~kg}$ ); since the $90^{\text {th }}$ day to the end of lactation, it increased moderately $(490.6 \pm 3.9$ against $504.8 \pm 3.7$ $\mathrm{kg}$ ).

On the $305^{\text {th }}$ day, the cows of the experimental group had a live weight of $504.8 \pm 3.7 \mathrm{~kg}$. Their live weight exceeded that in the control group by $13.8 \mathrm{~kg}(\mathrm{p} \leq 0.05)$. The difference is due to the introduction of vodnite into the basic diet. Milk productivity indicators are presented in Table 2. It was higher in the cows of the experimental group.

The highest milk yield was observed in cows of the experimental group on the 60th day of lactation and amounted to $19.23 \pm 1.11 \mathrm{~kg}$; in the experimental group, it was $20.76 \pm 0.98 \mathrm{~kg}$ or $7.4 \%$ less. During the experiment, the milk yield increased by $436 \mathrm{~kg}(8.0 \%)$. During the first month of lactation, fat content in milk of both groups was similar and amounted to $4.20 \pm 0.15$ and $4.21 \pm 0.08 \%$.

Since the $120^{\text {th }}$ to the $180^{\text {th }}$ day of lactation, fat content was increasing in both groups, but in the experimental group, it was $0.64 \%$ higher.

The dynamics of the mass fraction of protein corresponded to the physiological norms; during the experiment, there was no significant differences between the groups.

Fluctuations in the physico-chemical parameters of milk in cows of the control and experimental groups for the period of the first lactation are presented in table 3 .

The density of milk depends on the level of protein, fat, minerals. An analysis of the data obtained in the experiment indicates that the use of water-based mineral feed additive vodnite in addition to the diet of cows did not adversely affect the physical properties of milk. The milk density in experimental cows ranged from 1.027 to $1.031 \mathrm{~g} / \mathrm{cm}^{3}$, as in control animals.

The acidity of milk determines the ability to coagulate milk and affects the quality of products. The acidity of milk is provided by acid salts, proteins, carbon dioxide, lactic, citric, ascorbic acids and other components. This indicator in the control and experimental groups was in the range from 16.7 to $19.3^{\circ} \mathrm{T}$, which corresponds to the norm.

Table 2. Dynamics of milk production in fresh cows

\begin{tabular}{|c|c|c|c|c|c|}
\hline \multirow{2}{*}{ 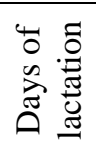 } & \multirow[b]{2}{*}{ 节 } & \multicolumn{4}{|c|}{ Indicators } \\
\hline & & $\begin{array}{l}\text { average daily milk } \\
\text { yield, } \mathrm{kg}\end{array}$ & $\begin{array}{c}\text { mass fraction of } \\
\text { fat, } \%\end{array}$ & $\begin{array}{c}\text { mass fraction of } \\
\text { protein, } \%\end{array}$ & $\begin{array}{l}\text { gross yield per } \\
\text { cow, } \mathrm{kg}\end{array}$ \\
\hline \multirow{2}{*}{10} & control & $17.03 \pm 0.63$ & $4.20 \pm 0.15$ & $3.35 \pm 0.14$ & $170.3 \pm 7.9$ \\
\hline & experiment & $16.82 \pm 0.51$ & $4.21 \pm 0.08$ & $3.33 \pm 0.12$ & $168.2 \pm 8.2$ \\
\hline \multirow{2}{*}{60} & control & $19.23 \pm 1.11$ & $4.08 \pm 0.13$ & $3.01 \pm 0.12$ & $576.9 \pm 23.2$ \\
\hline & experiment & $20.76 \pm 0.98$ & $4.05 \pm 0.11$ & $3.05 \pm 0.13$ & $622.8 \pm 18.2 *$ \\
\hline \multirow{2}{*}{120} & control & $17.81 \pm 1.11$ & $4.07 \pm 0.07$ & $3.03 \pm 0.10$ & $534.3 \pm 20.1$ \\
\hline & experiment & $19.83 \pm 0.87$ & $4.06 \pm 0.13$ & $3.10 \pm 0.08$ & $594.9 \pm 19.2 *$ \\
\hline \multirow[b]{2}{*}{180} & control & $15.55 \pm 1.31$ & $4.12 \pm 0.10$ & $2.96 \pm 0.05$ & $466.5 \pm 21.6$ \\
\hline & experiment & $17.73 \pm 0.73$ & $4.14 \pm 0.09$ & $3.02 \pm 0.12$ & $531.9 \pm 26.3$ \\
\hline \multirow[b]{2}{*}{240} & control & $12.13 \pm 0.51$ & $4.00 \pm 0.13$ & $3.02 \pm 0.08$ & $363.9 \pm 24.3$ \\
\hline & experiment & $13.72 \pm 1.12$ & $4.02 \pm 0.12$ & $2.87 \pm 0.11$ & $411.6 \pm 18.1$ \\
\hline \multirow{2}{*}{305} & control & $8.92 \pm 0.70$ & $3.95 \pm 0.08$ & $2.98 \pm 0.11$ & $267.6 \pm 18.2$ \\
\hline & experimental & $9.58 \pm 0.81$ & $4.01 \pm 0.06$ & $3.01 \pm 0.10$ & $287.4 \pm 13.5$ \\
\hline
\end{tabular}

Note: ${ }^{*}-\mathrm{p} \leq 0.05 ;{ }^{*}-\mathrm{p} \leq 0.01-$ relative to the control group 
Table 3. Dynamics of physical and chemical indicators of milk

\begin{tabular}{|c|c|c|c|c|c|}
\hline \multirow{2}{*}{$\begin{array}{c}\text { Days of } \\
\text { lactation }\end{array}$} & Group & \multicolumn{4}{|c|}{ Indicators } \\
\cline { 3 - 6 } & & density, $\mathrm{g} / \mathrm{cm}^{3}$ & acidity, ${ }^{\circ} \mathrm{T}$ & lactose, $\%$ & Dry matter, $\%$ \\
\hline \multirow{2}{*}{10} & control & $1.031 \pm 0.001$ & $19.3 \pm 0.1$ & $4.67 \pm 0.21$ & $13.14 \pm 0.47$ \\
\cline { 2 - 6 } & experimental & $1.030 \pm 0.002$ & $19.1 \pm 0.2$ & $4.65 \pm 0.17$ & $12.95 \pm 0.32$ \\
\hline \multirow{2}{*}{60} & control & $1.029 \pm 0.001$ & $17.5 \pm 0.1$ & $4.53 \pm 0.25$ & $12.85 \pm 0.29$ \\
\cline { 2 - 6 } & experimental & $1.027 \pm 0.001$ & $17.8 \pm 0.2$ & $4.59 \pm 0.14$ & $12.86 \pm 0.32$ \\
\hline \multirow{2}{*}{120} & control & $1.028 \pm 0.001$ & $17.1 \pm 0.3$ & $4.53 \pm 0.31$ & $12.69 \pm 0.32$ \\
\cline { 2 - 6 } & experimental & $1.029 \pm 0.002$ & $17.2 \pm 0.1$ & $4.62 \pm 0.09$ & $12.90 \pm 0.28$ \\
\hline \multirow{3}{*}{180} & control & $1.027 \pm 0.001$ & $17.6 \pm 0.2$ & $4.57 \pm 0.13$ & $12.65 \pm 0.23$ \\
\cline { 2 - 6 } & experimental & $1.029 \pm 0.001$ & $17.2 \pm 0.4$ & $4.68 \pm 0.21$ & $12.92 \pm 0.27$ \\
\hline \multirow{2}{*}{240} & control & $1.028 \pm 0.001$ & $17.2 \pm 0.2$ & $4.59 \pm 0.17$ & $12.61 \pm 0.13$ \\
\cline { 2 - 6 } & experimental & $1.030 \pm 0.001$ & $16.7 \pm 0.3$ & $4.75 \pm 0.14$ & $12.80 \pm 0.19$ \\
\hline \multirow{2}{*}{305} & control & $1.029 \pm 0.001$ & $16.9 \pm 0.4$ & $4.51 \pm 0.21$ & $12.56 \pm 0.26$ \\
\cline { 2 - 6 } & experimental & $1.030 \pm 0.001$ & $17.2 \pm 0.2$ & $4.66 \pm 0.16$ & $12.88 \pm 0.23$ \\
\hline
\end{tabular}

Cow's milk contains milk sugar (lactose) which is a source of energy, participates in the synthesis of fats and proteins, and is necessary for normal metabolism in the body. In the experimental group of cows during the experiment, the amount of lactose was higher from 1.31 to $3.36 \%$ compared with the same indices of the control group.

During the period of the studies, it was noted that the use of mineral feed additive vodnite in the diet of cows of the first lactation activates the activity of the whole organism, increases the absorption of carbohydrates by the mammary gland, and has a corrective effect on the physicochemical properties of milk.

Studies on effects of vodnite on the adaptation of the morphophysiological and immune-biological status of calves were conducted in the agricultural production company n.a. Kalyagin (Kinel district of Samara region). Control and experimental groups were formed from healthy calves according to the principle of analogues (30 animals in each group).

The control group - pure-bred calves of the blackmotley breed - received the main diet. The experimental group was daily fed with $3.0 \%$ which was heated at 110 ${ }^{\circ} \mathrm{C}$ for $40 \mathrm{~min}$ and fractionated.

Physiological, hematological, biochemical and immunological indicators of the 30-180-day old calves were recorded. At the age of 60 days, the number of red blood cells was $6.32 \%$ higher $(\mathrm{p} \leq 0.05)$; at the age of 100 days, it was higher by $3.03 \%$; at the age of 180 days - by $4.17 \%(\mathrm{p} \leq 0.05)$ compared with the similar data in the control group.

The total protein content in the blood of 40-day old experimental calves was $1.03 \%$ higher; in the blood of the 120 -day-old calves $-2.52 \%$ higher $(\mathrm{p} \leq 0.05)$; in the blood of 160-day-old calves $-3.10 \%$ higher $(p \leq 0.01)$; in the blood of 180 -day-old calves $-6.44 \%$ higher $(p \leq 0.01)$.

The amount of main albumin growth protein was higher by $4.60 \%(\mathrm{p} \leq 0.01)$ relative to that in the control. The content of $\gamma$-globulin in blood in the 80-day-old experimental calves was higher by $3.08 \%$ and in 180 day-old calves - by $8.10 \%(\mathrm{p} \leq 0.001)$.

The redox reactions of the body were maximum in the 180-day-old calves. The body temperature was 38.60 $\pm 0.19{ }^{\circ} \mathrm{C}$, the pulse rate was $73.80 \pm 0.83 \mathrm{bpm}$, and the respiration rate was $24.50 \pm 1.19$ resp. movement / min., the number of red blood cells was $7.18 \pm 0.32 \cdot 1012 / 1$, the number of white blood cells was $6.73 \pm 1.57 \cdot 109 / 1$, the hemoglobin level was $127.90 \pm 2.40 \%$, the activity of aspartate aminotransferase was $93.60 \pm 1.36 \mathrm{U} / 1$.

By the age of 180 days, the phagocytic activity of leukocytes was $12.42 \%$ higher $(\mathrm{p} \leq 0.05)$, bactericidal activity in blood serum was $6.47 \%$ higher $(\mathrm{p} \leq 0.05)$. In the experimental group, lysozyme activity was higher by $10 \%(\mathrm{p} \leq 0.05)$ relative to the control parameter.

\section{Discussion}

The use of vodnite for calves increased the nonspecific resistance of the body, had a positive influence on cellular and humoral factors of the body defense. High adaptive indices of calves fed with vodnite determined the best productive characteristics: animal safety, live weight and average daily gain (Table 4).

On the $180^{\text {th }}$ day, the average daily gain in the body weight increased by $7.4 \%$; the live weight - by $7.6 \%$ $(\mathrm{p} \leq 0.01)$; animal safety - by $7.5 \%$ relative to the control indicators. 
Table 4. Growth dynamics for calves fed with vodnite

\begin{tabular}{|c|c|c|}
\hline \multirow[b]{2}{*}{ Indicators } & \multicolumn{2}{|c|}{ Group } \\
\hline & Control & Experimental \\
\hline \multicolumn{3}{|c|}{40 days } \\
\hline Live weight, $\mathrm{kg}$ & $55.10 \pm 1.61$ & $56.93 \pm 1.67$ \\
\hline Daily average gain, $\mathrm{g}$ & $433 \pm 9.98$ & $478 \pm 9.71$ \\
\hline \multicolumn{3}{|c|}{60 days } \\
\hline Live weight, kg & $65.22 \pm 1.84$ & $68.44 \pm 1.71$ \\
\hline Daily average gain, $\mathrm{g}$ & $533 \pm 10.11$ & $606 \pm 10.48$ \\
\hline \multicolumn{3}{|c|}{80 days } \\
\hline Live weight, kg & $84.10 \pm 1.75$ & $89.92 \pm 1.61 *$ \\
\hline Daily average gain, $\mathrm{g}$ & $743 \pm 11.64$ & $846 \pm 11.05$ \\
\hline \multicolumn{3}{|c|}{100 days } \\
\hline Live weight, kg & $92.56 \pm 1.80$ & $99.20 \pm 1.73 *$ \\
\hline Daily average gain, $\mathrm{g}$ & $669 \pm 10.78$ & $716 \pm 11.23$ \\
\hline \multicolumn{3}{|c|}{120 days } \\
\hline Live weight, kg & $105.45 \pm 1.79$ & $110.91 \pm 1.58^{*}$ \\
\hline Daily average gain, $\mathrm{g}$ & $637 \pm 10.17$ & $683 \pm 10.82$ \\
\hline \multicolumn{3}{|c|}{160 days } \\
\hline Live weight, kg & $121.67 \pm 1.82$ & $130.17 \pm 1.88^{* *}$ \\
\hline Daily average gain, $\mathrm{g}$ & $559 \pm 10.05$ & $581 \pm 10.32$ \\
\hline \multicolumn{3}{|c|}{180 days } \\
\hline Live weight, kg & $140.47 \pm 2.13$ & $151.18 \pm 2.09^{* *}$ \\
\hline Daily average gain, $\mathrm{g}$ & $614 \pm 10.41$ & $663 \pm 10.33$ \\
\hline
\end{tabular}

of zeolite basis preparation in fattening lambs diet Biological animals 28, 545-552 (2012)

\section{Conclusion}

Based on the above studies, it is possible to suggest using mineral enterosorbent vodnite as a feed additive for calves and fresh cows in order to improve the morphophysiological, biochemical and immunological status of animals, increase the genetically inherent potential of animal productivity indicators. Vodanite increased the total meat and milk sales revenue, decreased the production cost and increased profit per head by 511.25 rubles in the experiment with calves and by 1050.1 rubles in the experiment with fresh cows.

\section{References}

1. S.V. Dezhatkina, N.A. Lubin, A.V. Dosorov, M. E. Dezhatkin, The use of soy okara in feeding of pigs Res. J. of Pharmaceutical. Biological and Chemical Sci. 7(5), 2573-2577 (2016) DOI:10.1016/j. wasman. 2018.01.015.

2. M. Mercurio, P. Cappelletti, B. de Gennaro, The effect of digestive activity of pig gastro-intestinal tract on zeolite-rich rocks: An in vitro stud. Microporous and mesoporous materials 225, 133136 (2016)

3. J. Stojkovic, Z. Ilic, S. Ciric, B. Ristanovic, M.P. Petrovic, V. Caro Petrovic, V. Kurcubic, Efficiency
4. Q. Wang, M. K. Awasthi, X. Ren, Combining biochar, zeolite and wood vinegar for composting of pig manure: The effect on greenhouse gas emission and nitrogen conservation Waste Management 74, 221-230 (2018)

5. H. Valpotic, D. Gracner, R. Turk, Zeolite clinoptilolite nanoporous feed additive for animals of veterinary importance: potentials and limitations Periodicum biologorum 119(3), 159-172 (2017)

6. E. Burcak, S. Yalcin, Effects of dietary sepiolite usage on performance. carcass characteristics. blood parameters and rumen fluid metabolites in Merino cross breed lambs Appl. clay sci. 163, 291298 (2018)

7. B. Sulistiyanto, C.S. Utama, S. Sumarsih, Effect of binder mineral in batchery waste based feed pellet on its proximate component and energy values $\mathrm{J}$. of the Indonesian tropical animal agriculture 43(2), 107-114 (2018)

8. M.V. Zabelina, G.V. Molyanova, V.P. Kartashev, I.F. Vilkovysky, A.A. Strizhakov, Reproductive indicators of cows with varying degrees of blood on holstein Res. J. of Pharmaceutical. Biological and Chemical Sci. 9(6), 1049 -1055 (2018)

9. V.V. Zaitsev, O.N. Makurina, G.V. Molyanova, A.V. Savinkov, A.M. Ukhtverov, V.V. Tarabrin, Hemostasis and rheological blood features 
dynamics of black-many coloured lactating cows at the inclusion into their ration of antioxidant lipisomal preparation "lipovitam-beta" Biomedical and Pharmacology J. 10(2), 759-766 (2017)
10. L.V. Toporova, S.N. Serebrennikova, V.V. Galashov, V.E. Lutsuk, I.V. Toporova, V.V. Andreev, The effectiveness of organomineral additives in animal feeding Chief livestock specialist 1, 16-26 (2012) 